\title{
Performansi Alat Pengering Terowongan Tenaga Surya Tipe Hohenheim untuk Pengeringan Kerupuk Tiram
}

\author{
The Performance of Type Hohenheim Solar Tunnel Dryer in Drying Oyster Kerupuk \\ Rita Khathir*, Eka Pratika Sari, Raida Agustina \\ Jurusan Teknik Pertanian, Fakultas Pertanian, Universitas Syiah Kuala, \\ Jl. Tgk. H. Hasan Krueng Kalee No. 3 Darussalam, Banda Aceh 23111, Indonesia \\ *Penulis korespondensi: Rita Khathir, E-mail: rkhathir@unsyiah.ac.id
}

Tanggal submisi: 19 Januari 2019; Tanggal penerimaan: 26 Februari 2020

\begin{abstract}
ABSTRAK
Penelitian ini bertujuan untuk mengetahui performansi alat pengering terowongan tipe Hohenheim pada proses pengeringan kerupuk tiram. Alat pengering terowongan tipe Hohenheim adalah alat pengering berbasis energi matahari yang bekerja dengan gabungan prinsip efek rumah kaca dan kolektor surya. Sebuah alat pengering tipe ini dibuat dengan dimensi panjang $2 \mathrm{~m}$ dan lebar $1 \mathrm{~m}$. Luas alas pengering $1,5 \mathrm{~m}^{2}$ dan luas absorber $0,5 \mathrm{~m}^{2}$. Pengeringan kerupuk tiram dilakukan dengan variasi tebal lapisan pengeringan yaitu 2, 4, dan $6 \mathrm{~mm}$. Parameter penelitian meliputi iradiasi surya, suhu, kelembaban relatif $(\mathrm{RH})$, kadar air, dan kadar protein. Hasil penelitian menunjukkan bahwa rata-rata iradiasi surya 370-390 W/m², dan pengeringan berpotensi dilakukan dari jam 9.00-17.00 WIB, setiap hari. Rata-rata suhu ruang pengering 39,7-40,9 ${ }^{\circ} \mathrm{C}$, sedangkan rata-rata suhu lingkungan adalah $31,3-31,6{ }^{\circ} \mathrm{C}$. Rata-rata $\mathrm{RH}$ dalam ruang pengering adalah $47,8-50,5 \%$, yang mana lebih rendah dari $\mathrm{RH}$ lingkungan. Pengeringan ketebalan lapisan $2 \mathrm{~mm}$ membutuhkan waktu selama 10 jam, dan pengeringan ketebalan lapisan $4 \mathrm{~mm}$ dan $6 \mathrm{~mm}$ membutuhkan waktu selama 12 jam. Kadar air kerupuk tiram yang dikeringkan dengan ketebalan lapisan $2 \mathrm{~mm}$ adalah 6,5\%, sedangkan pengeringan ketebalan lapisan 4 dan $6 \mathrm{~mm}$ menghasilkan kerupuk tiram dengan kadar air 10,08\% dan 9,68\%. Kadar protein kerupuk tiram pada pengeringan ketebalan lapisan $2 \mathrm{~mm}$ sebesar $6,52 \%, 4 \mathrm{~mm}$ sebesar 7,62\% dan $6 \mathrm{~mm}$ sebesar 8,89\%. Alat pengering terowongan tipe Hohenheim layak digunakan untuk proses pengeringan kerupuk tiram dengan ketebalan lapisan $6 \mathrm{~mm}$ dalam waktu yang singkat, namun penelitian lanjutan untuk modifikasi alat pengering masih perlu dilakukan.
\end{abstract}

Kata kunci: Lapisan pengeringan; pengering terowongan Hohenheim; kerupuk tiram

\begin{abstract}
The aim of this study is to evaluate the performance of type Hohenheim solar tunnel dryer in drying Oyster kerupuk. This dryer was designed based on solar energy under two systems i.e. by using a solar collector and a greenhouse effect. The dryer has a dimension of $2 \mathrm{~m}$ length and $1 \mathrm{~m}$ width, with about $1.5 \mathrm{~m}^{2}$ and $0.5 \mathrm{~m}^{2} \mathrm{drying}$ and absorber area, respectively. In addition, oyster kerupuk were dried at 3 different depth layers, including at 2,4 , and $6 \mathrm{~mm}$, and the parameters observed comprise solar irradiation, temperature and humidity, moisture and the protein content of oyster kerupuk. The results showed an average solar irradiation of $370-390 \mathrm{~W} / \mathrm{m}^{2}$, with potential application between $9.00 \mathrm{am}-17.00 \mathrm{pm}$, daily. Moreover, the temperature at the drying chamber was gained within the range $39.7-40.9^{\circ} \mathrm{C}$, while the average ambient temperature was $31.3-3.6^{\circ} \mathrm{C}$. The drying chamber had a relative humidity of $47.8-50.5 \%$, and was reportedly lower than the ambient value. Furthermore, the drying time used at a $2 \mathrm{~mm}$ layer depth was $10 \mathrm{~h}$, while 12 hours was required for the 4 and $6 \mathrm{~mm}$. The moisture content of samples at 2,4 , and $6 \mathrm{~mm}$ was $6.5 \%, 10.08$ and $9.68 \%$, respectively, while the protein
\end{abstract}


composition was $6.52 \%, 7.62 \%$, and $8.89 \%$, correspondingly. Hence, the Hohenheim tunnel dryer is estimated to possess adaptive characteristics required for the drying process of oyster kerupuk at the $6 \mathrm{~mm}$ depth, although further evaluation is needed to improve its performance.

Keywords: Drying layer; Hohenheim tunnel dryer; oyster kerupuk

\section{PENDAHULUAN}

Tiram (Crassostrea gigas) adalah hasil sumber daya daerah pesisir yang mengandung gizi tinggi seperti protein, zinc, vitamin A, dan vitamin C (Puspita, 2017) sehingga berpotensi untuk menjadi solusi bagi masalah stunting (Mustamin dkk., 2019). Pengolahan tiram menjadi kerupuk tiram adalah salah satu upaya diversifikasi pangan untuk meningkatkan nilai tambah produk ini (Berlia dkk., 2017) bagi masyarakat pesisir. Hal ini diharapkan dapat meningkatkan kesehatan dan kesejahteraan hidup masyarakat, sekaligus menjadi usaha promosi produk lokal ke daerah lain yang dapat berdampak pada aspek sosial ekonomi yang lebih luas.

Kerupuk dikenal sebagai teman makan nasi ataupun sebagai makanan kecil yang disukai oleh hampir semua kalangan tanpa mengenal usia (Setiyorini dan Hadi, 2013). Kerupuk adalah makanan kering yang dibuat dari tapioka atau tepung sagu dengan atau tanpa penambahan bahan makanan atau bahan tambahan makanan lain yang diinginkan, yang disiapkan dengan cara menggoreng atau memanggang sebelum disajikan. Salah proses penting dalam proses produksi kerupuk tiram adalah proses pengeringan. Secara umum, masyarakat biasanya mengeringkan kerupuk menggunakan metode pengeringan dengan memanfaatkan energi matahari sebagai sumber panas dan produk diletakkan di atas terpal plastik. Produsen kerupuk tiram mengeringkan kerupuk di atas nampan yang dibuat dari kulit bambu, diletakkan di bawah sinar matahari di tempat terbuka (Khathir dkk., 2018). Hal ini merupakan hal yang sudah sangat umum dan dapat dijumpai pada industri kerupuk lainnya seperti kerupuk teripang di Sukolilo Surabaya (Anggraini and Yudhastuti, 2014).

Pengeringan alternatif dapat dilakukan dengan alat pengering terowongan tipe Hohenheim dengan keuntungan proses pengeringan lebih cepat, produknya terlindungi dari kontaminasi, serta proses pengeringan yang lebih mudah karena tidak perlu ditungguin. Alat pengering terowongan tenaga surya tipe Hohenheim sudah diuji untuk Pliek-U (Al-Hasani dkk., 2017; Khathir dkk., 2015) cabai merah (Ridwan dkk., 2017), jahe merah (Mentari dkk., 2017), jahe gajah (Rahmadi, 2019), dan kopi gayo (Hardi, 2019). Dalam mendukung perkembangan usaha mikro produksi kerupuk tiram, peningkatan teknologi pengeringan merupakan faktor yang secara signifikan akan mempengaruhi kualitas kerupuk tiram yang dihasilkan. Dengan kata lain sangat dibutuhkan penerapan good manufacturing practices (Anggraini dan Yudhastuti, 2014).

Salah satu faktor yang mempengaruhi kualitas pengeringan kerupuk adalah ketebalan lapisan pengeringan. Kajian variasi ketebalan lapisan pengeringan sangat penting dilakukan untuk menentukan kapasitas pengeringan yang optimum. Pengeringan yang terlalu tipis akan menghasilkan kerupuk yang sangat kering sehingga mudah patah serta menyebabkan kapasitas pengeringan lebih rendah, sedangkan pengeringan yang terlalu tebal akan menghasilkan kerupuk yang kurang kering, kadar air tidak merata, umur simpan singkat karena mudah diserang jamur, dan kerupuk yang kurang mengembang ketika digoreng. Oleh karena itu penelitian ini bertujuan untuk mengetahui performansi alat pengering terowongan tipe Hohenheim dalam mengeringkan kerupuk tiram dengan variasi ketebalan irisan kerupuk.

\section{METODE PENELITIAN}

\section{Bahan}

Bahan utama yang digunakan dalam penelitian ini adalah tiram (Crassostrea gigas) sebanyak $2 \mathrm{~kg}$ yang diperoleh dari nelayan Desa Gampong Blang Kecamatan Meuraxa Kota Banda Aceh. Bahan lain digunakan adalah bahan untuk proses pembuatan kerupuk yaitu air (1000 $\mathrm{mL})$, tepung terigu $(1 \mathrm{~kg})$, tapioka $(0,5 \mathrm{~kg})$, telur (1 butir), bawang putih, ketumbar, dan garam secukupnya.

\section{Alat}

Peralatan-peralatan yang digunakan adalah 1 unit alat pengering terowongan tenaga surya tipe Hohenheim (Gambar 1), solarimeter, HTC meter (HumidityTemperature-Clock), anemometer, dan timbangan. Alat pengering yang diuji dapat dilihat pada Gambar 1.

Sebagaimana dapat dilihat pada Gambar 1, alat ini berdimensi panjang $2 \mathrm{~m}$ dan lebar $1 \mathrm{~m}$. Modifikasi dari alat yang diteliti sebelumnya diberikan dengan penambahan 1 unit kipas outlet dengan spesifikasi 12 Volt 0,2A DC diameter $12 \mathrm{~cm}$ untuk mengeluarkan uap air hasil pengeringan. Sebanyak 2 unit kipas dengan 


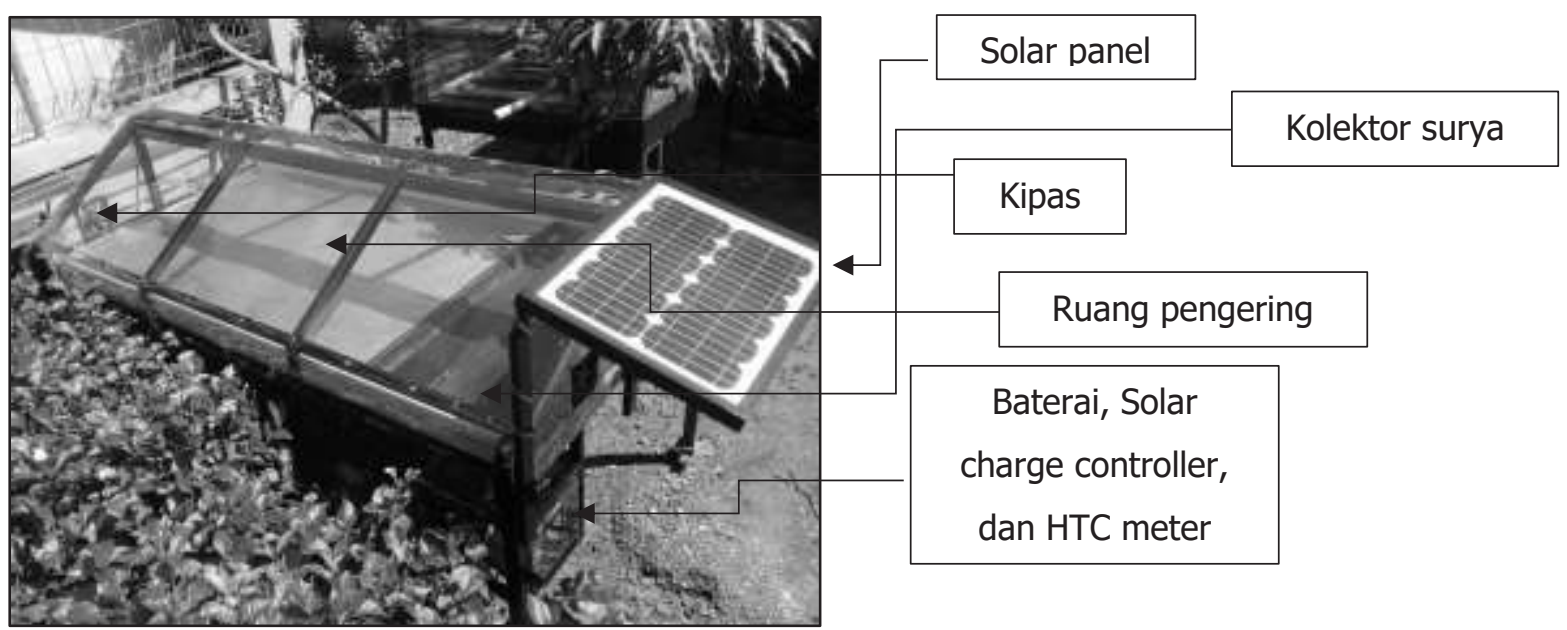

Gambar 1. Alat pengering terowongan tenaga surya tipe Hohenheim

spesifikasi yang sama digunakan pada bagian inlet. Selain itu alat ini berukuran lebih kecil dibandingkan alat pengering terowongan tenaga surya tipe Hohenheim yang sudah diuji sebelumnya. Sebuah solar panel 20 WP digunakan untuk menghasilkan tegangan listrik. Arus yang dihasilkan disimpan melalui 1 unit solar charge controller MPPT 20 A ke dalam baterai berkapasitas 18 ah. Alas pengering dibuat dari pelat aluminium dengan luas $1,5 \mathrm{~m}^{2}$, sedangkan luas absorber pada kolektor surya adalah 0,5 $\mathrm{m}^{2}$. Bagian absorber dibuat dari seng gelombang berwarna hitam, dan bagian penutup transparan pada alat dibuat dari polycarbonate sheet $0,8 \mathrm{~mm}$. Untuk memudahkan proses pemindahan alat, pada keempat kaki alat pengering diberikan roda.

\section{Prosedur Kerja}

Pengujian performansi alat pengering tipe terowongan Hohenheim dilaksanakan dengan menguji proses pengeringan kerupuk tiram. Tiram dicuci bersih dan dihaluskan menggunakan blender. Adonan kerupuk dibuat dengan mencampurkan semua bahan, lalu dimasukkan ke dalam kantung plastik dan direbus. Adonan kerupuk tiram yang sudah direbus dan didinginkan, diiris dengan ketebalan $2 \mathrm{~mm}$ menggunakan pisau. Prosedur pembuatan kerupuk ini mengikuti prosedur yang diaplikasikan oleh usaha mikro setempat.

Prosespengeringan dilakukan dengan menyebarkan kerupuk dalam alat pengering dengan variasi tebal lapisan pengeringan yaitu 2, 4, dan $6 \mathrm{~mm}$ seperti dapat dilihat pada Gambar 2. Posisi penyebaran kerupuk dilakukan melintang dengan posisi absorber. Sebelum dan sesudah pengeringan dilakukan analisis kadar air (metode oven) dan kadar protein (metode kjeldah). Proses pengeringan dilaksanakan dari jam 9.00-17.00 WIB, disesuaikan dengan potensi iradiasi matahari.

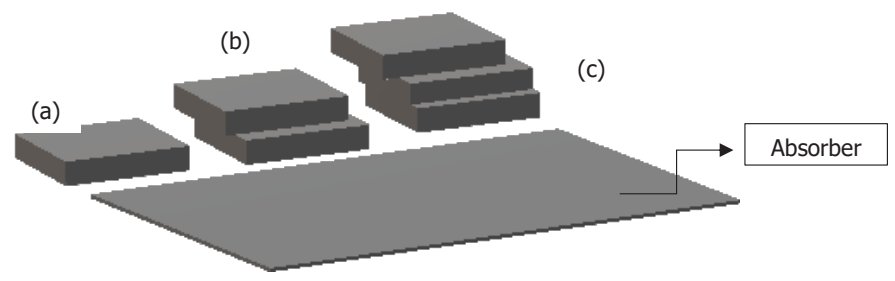

Gambar 2. Pola peletakan kerupuk tiram berdasarkan ketebalan lapisan (a) $2 \mathrm{~mm}$, (b) $4 \mathrm{~mm}$, dan (c) $6 \mathrm{~mm}$, melintang posisi absorber

Proses pengeringan bersifat intermitten karena pada malam hari tidak memungkinkan dilakukan. Selama proses pengeringan dilakukan pengamatan data iradiasi surya, suhu, kelembaban relatif $(\mathrm{RH})$, dan penurunan berat sampel, dalam interval 1 jam.

\section{Teknik Analisa Data}

Total iradiasi matahari dihitung dengan metode Simpson menggunakan Persamaan 1 (Zamharir dkk., 2016), dan rata-rata iradiasi dihitung dengan Persamaan 2. Pengolahan data dilakukan dengan statistik deskriptif menggunakan parameter nilai rerata (Persamaan 3) dan standar deviasi (Persamaan 4). Nilai rendemen kerupuk tiram dihitung dengan Persamaan 5. Hasil olahan data ditampilkan secara deskriptif dalam bentuk grafik dan tabel.

$$
\begin{aligned}
I_{h} & =\frac{\Delta t}{3}\left[I_{i}+4 \sum I_{t g l}+2 \sum I_{t g f}+I_{f}\right] \\
\bar{I} & =\frac{I_{h}}{n-1} \\
\bar{X} & =\frac{\sum_{i=1}^{n} X_{i}}{n} \\
\sigma & =\sqrt{\frac{\sum_{i=1}^{n}\left(X_{i}-\bar{X}\right)^{2}}{n-1}} \\
R & =\frac{\mathscr{W}_{f}}{W_{i}} \times 100 \%
\end{aligned}
$$




\section{HASIL DAN PEMBAHASAN}

\section{Ketersediaan Energi Pengeringan}

Hasil penelitian menunjukkan bahwa total iradiasi matahari yang diperoleh pada hari pertama pengeringan adalah $2.436,43 \mathrm{~W} / \mathrm{m}^{2}$, dimana proses pengeringan dilakukan selama 7 jam. Sedangkan total iradiasi matahari pada hari kedua pengeringan adalah 1.850,77 $\mathrm{W} / \mathrm{m}^{2}$, dengan durasi proses pengeringan selama 5 jam. Rata-rata iradiasi surya yang diperoleh adalah 348-370 W/m². Berdasarkan data amatan iradiasi surya pada Gambar 3, proses pengeringan sangat potensial dilakukan antara pukul 11.00 - 14.00 WIB karena nilai perolehan iradiasi surya pada rentang waktu tersebut berada di atas nilai rata-rata harian yang diperoleh. Nilai capaian iradiasi surya ini didukung oleh penelitian Ridwan dkk. (2017), dimana mereka mengidentifikasikan nilai rata-rata iradiasi matahari sebesar $383,73 \mathrm{~W} / \mathrm{m}^{2}$.

Alat pengering terowongan Hohenheim adalah alat yang bekerja dengan sumber energi terbarukan dari matahari. Dalam hal ini, iradiasi surya dimanfaatkan dengan 2 metode yaitu (1) proses konversi radiasi surya menjadi energi panas, dan (2) proses konversi radiasi surya menjadi energi listrik. Proses konversi energi panas dilakukan dengan 2 cara yaitu menggunakan mekanisme efek rumah kaca (ERK), dan menggunakan kolektor surya. Mekanisme efek rumah kaca diperoleh dengan terperangkapnya radiasi matahari dalam kurungan permukaan transparan yang sekaligus berfungsi untuk melindungi produk yang dikeringkan. Sedangkan kolektor surya adalah sebuah panel yang terdiri dari beberapa bagian yang bersifat mengumpulkan radiasi matahari menggunakan permukaan berwarna hitam yang berada di bawah permukaan transparan. Sedangkan energi matahari yang dikonversikan menjadi energi listrik disimpan dalam sebuah baterai yang memungkinkan dipakai untuk sistem sirkulasi udara dan sistem penerangan.

Prinsip kerja alat ini sangat membantu proses pengeringan karena tingginya tingkat fluktuasi radiasi

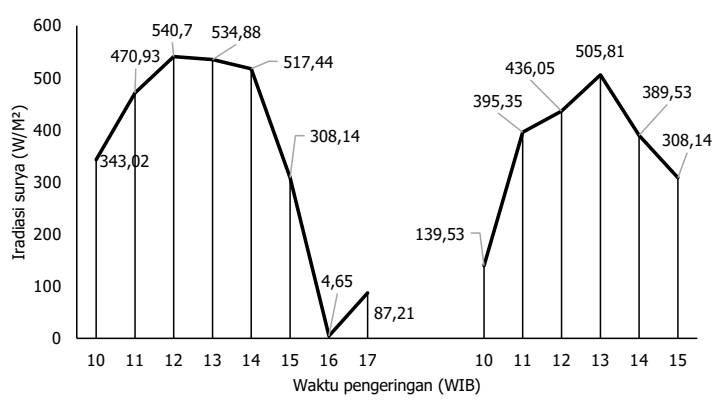

Gambar 3. Iradiasi matahari selama proses pengeringan kerupuk tiram matahari. Berdasarkan beberapa penelitian yang telah dilakukan (Khathir dkk., 2015; Mentari dkk., 2017; Ridwan dkk., 2017; Hardi, 2019; Rahmadi, 2019) maka sistem pengeringan ini sangat layak untuk dipergunakan, dimana ketersediaan energi matahari sangat berlimpah sepanjang tahun dengan rata-rata durasi proses pengeringan 7-8 jam per hari yang dapat dioptimalkan antara pukul 8.00-17.00 WIB.

\section{Suhu dan Kelembaban Relatif Pengeringan Menggunakan Alat Pengering Terowongan Hohenheim}

Indikator pertama yang digunakan untuk melihat performansi alat pengering adalah berapa suhu pengeringan yang dihasilkan. Berdasarkan hasil penelitian, suhu pengeringan rata-rata dalam ruang pengering Hohenheim adalah $39,77^{\circ} \mathrm{C}$, dengan standar deviasi sebesar $4,42{ }^{\circ} \mathrm{C}$ (Gambar 4a). Sedangkan suhu rata-rata di lingkungan alat pengering adalah $31,63{ }^{\circ} \mathrm{C}$, dengan standar deviasi $1,35^{\circ} \mathrm{C}$. Dapat dijelaskan bahwa dengan disain alat seperti ini dan hanya bersumberkan energi matahari, suhu pengeringan dapat ditingkatkan sebesar $8,14^{\circ} \mathrm{C}$ dari suhu lingkungan. Hasil penelitian ini didukung oleh Mentari dkk. (2017), yang menyatakan bahwa suhu dalam alat pengering dapat ditingkatkan sebesar $9^{\circ} \mathrm{C}$.

Penelitian sebelumnya terhadap alat pengering terowongan Hohenheim berdimensi panjang $6 \mathrm{~m}$ dan lebar $2 \mathrm{~m}$ menghasilkan suhu pengeringan yang lebih tinggi, walaupun rerata iradiasi surya yang diperoleh tidak jauh berbeda. Khathir dkk. (2015), dalam evaluasi perdana terhadap alat pengering terowongan Hohenheim, menyatakan bahwa suhu dalam alat pengering dapat ditingkat sampai $20{ }^{\circ} \mathrm{C}$, namun demikian fluktuasi suhu dalam alat pengering sangat tinggi yaitu mencapai $\pm 9^{\circ} \mathrm{C}$, sedangkan flutuasi suhu lingkungan sekitar $\pm 1{ }^{\circ} \mathrm{C}$. Sedangkan Ridwan dkk. (2017), mengidentifikasikan suhu pengeringan dalam alat sebesar $42-62{ }^{\circ} \mathrm{C}$. Selanjutnya, Al-Hasani dkk. (2017) mengkonfirmasikan bahwa alat pengering terowongan Hohenheim dapat meningkatkan suhu sebesar $12-16^{\circ} \mathrm{C}$ dari suhu lingkungan, dan Rahmadi (2019) mengkonfirmasikan suhu dalam alat dapat ditingkatkan sebesar $17^{\circ} \mathrm{C}$. Hardi (2019) menemukan bahwa ketika diuji di daerah dataran tinggi Gayo, alat pengering terowongan Hohenheim dapat meningkatkan suhu pengeringan antara $10-20^{\circ} \mathrm{C}$. Dengan demikian suhu pengeringan dapat ditingkatkan secara signifikan menggunakan alat pengering tenaga surya terowongan tipe Hohenheim.

Pemanfaatan sistem pemanasan berdasarkan efek rumah kaca sudah banyak juga diteliti sebelumnya dan mampu meningkatkan suhu ruang pengering sebesar 


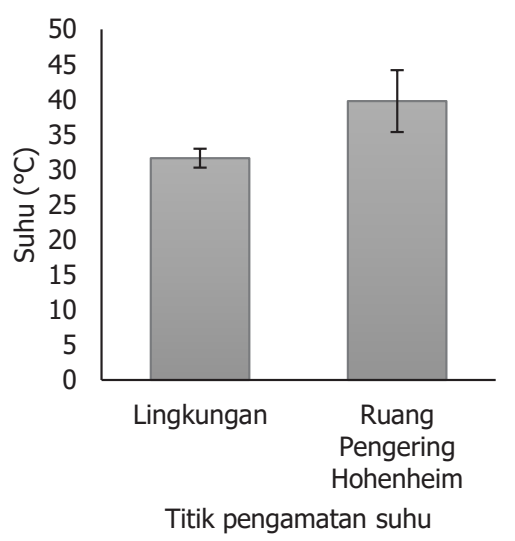

(a)

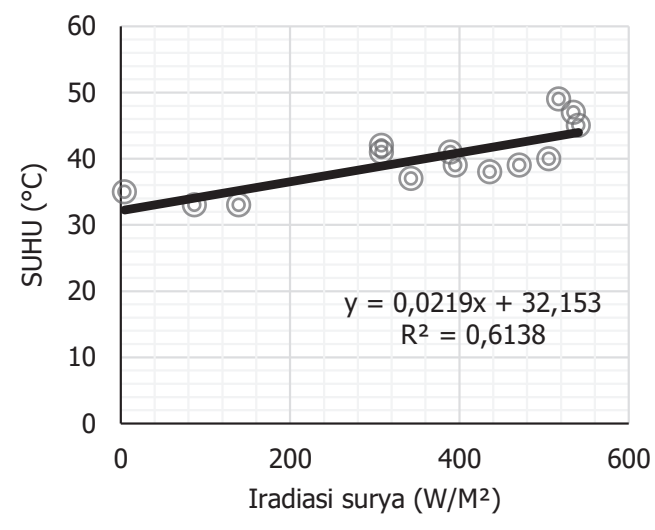

(b)

Gambar 4. (a) Perbandingan suhu pengeringan di lingkungan dan dalam ruang pengering Hohenheim dan (b) hubungan iradiasi surya dan suhu dalam ruang pengering

$13,2^{\circ} \mathrm{C}$, salah satunya adalah penelitian Zamharir dkk. (2016). Mereka mengidentifikasikan adanya perbedaan suhu antara tingkatan dalam ruang pengering, dimana suhu tingkat atas lebih tinggi dari suhu tingkat tengah dan bawah. Masalah ini dapat dikurangi pada sistem pengering terowongan karena sistem pengeringannya hanya satu tingkatan/lapisan, serta adanya penambahan kolektor surya yang langsung dibuat dalam bangunan pengeringnya.

Lebih lanjut dari Gambar 4b, hubungan (R-value) antara iradiasi surya dan suhu ruang pengering adalah 0,78 yang menunjukkan ada hubungan kuat yang positif. Peningkatan nilai iradiasi surya sebesar $1 \mathrm{~W} / \mathrm{m}^{2}$ akan meningkatkan suhu ruang pengering sebesar 0,0219 ${ }^{\circ} \mathrm{C}$. Faktor iradiasi surya dapat menjelaskan fenomena suhu dalam ruang pengering sebesar $61,38 \%\left(R^{2}-\right.$ value), atau dengan kata lain masih terdapat 38,62\% faktor lain yang berkonstribusi pada suhu dalam ruang pengering, misalnya kecepatan aliran udara pengering dan jenis bahan yang dikeringkan.

Adapun kelembaban relatif ruang pengering berada pada kisaran $47,8-50,5 \%$. Nilai kelembaban ini lebih rendah dari kelembaban relatif lingkungan, yang mana menunjukkan bahwa iklim mikro dalam alat sudah menunjang proses pengeringan. Nilai kelembaban relatif yang sama dikonfirmasikan pada penelitian sebelumnya yaitu $39 \pm 19 \%$ (Khathir dkk., 2015) dan 51,5\% (Mentari dkk., 2017). Fungsi kelembaban yang baik untuk proses pengeringan sangat didukung oleh adanya sistem aliran udara yang dihasilkan oleh kipas.

\section{Pola Pengeringan Kerupuk Tiram Dengan Variasi Lapisan Pengeringan}

Pola pengeringan kerupuk tiram dapat dilihat pada Gambar 5, dimana menjelaskan bahwa pada hari pertama, proses pengeringan terjadi lebih cepat pada ketebalan lapisan pengeringan $2 \mathrm{~mm}$. Sedangkan proses pengeringan lapisan 4 dan $6 \mathrm{~mm}$ berlangsung dengan kecepatan yang sama sepanjang proses pengeringan sehingga tampak bahwa kurva perubahan kadar airnya saling bertimpa. Proses pengeringan kerupuk tiram berlangsung selama 2 hari, dimana durasi pengeringan pada hari pertama adalah 7 jam, dan durasi pengeringan hari kedua adalah 5 jam. Pengeringan kerupuk tiram dengan ketebalan lapisan pengering $2 \mathrm{~mm}$ berlangsung selama 10 jam, sedangkan pengeringan pada ketebalan lapisan 4 dan $6 \mathrm{~mm}$ berlangsung selama 12 jam. Perbedaan penurunan berat kerupuk tiram pada setiap variasi ketebalan lapisan pengeringan pada hari kedua tidak ekstrim; hal ini dapat disebabkan oleh sudah rendahnya kadar air kerupuk. Berdasarkan hasil penelitian ini, pengeringan kerupuk tiram menggunakan alat pengering terowoongan Hohenheim cukup efektif dilakukan dengan ketebalan lapisan $6 \mathrm{~mm}$ untuk meningkatkan kapasitasnya 3 kali lipat dibandingkan pengeringan dengan ketebalan lapisan $2 \mathrm{~mm}$.

Perubahan ekstrim berat kerupuk terjadi pada hari pertama penqerinqan, dimana kadar air awalnva

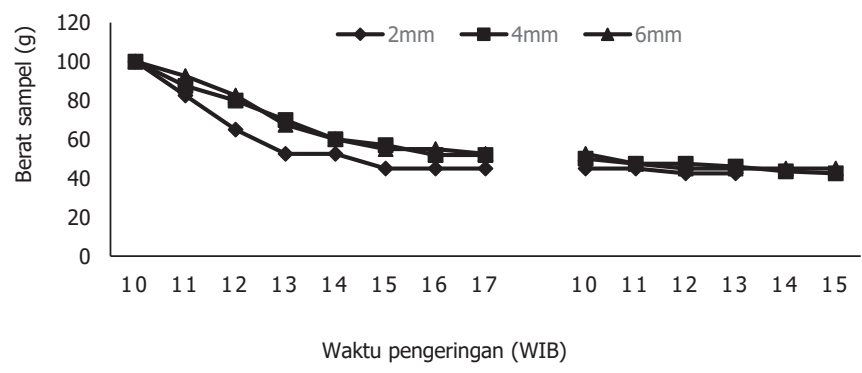

Gambar 5. Pola perubahan berat kerupuk tiram selama pengeringan 
masih tinggi yaitu $61,41 \%$. Pada hari kedua proses pengeringan, perubahan berat sampel kerupuk tiram sangat sedikit. Hal ini sesuai dengan kadar air akhir yang diperoleh, dimana kerupuk tiram yang dikeringkan dengan ketebalan $2 \mathrm{~mm}$ mempunyai kandungan air sebesar 6,05\%, sedangkan kerupuk yang dikeringkan dengan ketebalan $4 \mathrm{~mm}$ berkadar air 10,08\% dan yang dikeringkan dengan ketebalan $6 \mathrm{~mm}$ berkadar air 9,68\%. Dengan durasi pengeringan 10-12 jam, rendemen kerupuk tiram yang diperoleh adalah $32,6 \pm 0,7 \%$.

\section{Kualitas Kerupuk Tiram}

Berdasarkan Tabel 1, kerupuk tiram yang dikeringkan dengan alat pengering terowongan Hohenheim sudah baik, dapat dilihat dengan tingkat kadar airnya yang sudah memenuhi standar SNI 2714.1:2009 untuk kerupuk udang yaitu maksimal $12 \%$ dan untuk protein yaitu minimal $8 \%$ (mutu I) dan minimal 5\% (mutu II) (BSN, 2009). Namun pada ketebalan lapisan pengeringan $2 \mathrm{~mm}$, kadar air kerupuk tiram sudah terlalu rendah sehingga menyebabkan kerupuk yang dihasilkan sangat rapuh dan mudah hancur, dimana hal ini akan menimbulkan masalah baru bagi konsumen. Dengan demikian durasi pengeringan dapat diperpendek lagi, supaya kadar air kerupuk tiram yang dihasilkan berada pada kisaran $10-12 \%$.

Tabel 1. Karakteristik kerupuk tiram dengan variasi ketebalan lapisan pengeringan

\begin{tabular}{|c|c|c|c|}
\hline \multirow[t]{2}{*}{ Atribut kimia } & \multicolumn{3}{|c|}{$\begin{array}{c}\text { Ketebalan lapisan pengeringar } \\
\text { kerupuk tiram }\end{array}$} \\
\hline & $2 \mathrm{~mm}$ & $4 \mathrm{~mm}$ & $6 \mathrm{~mm}$ \\
\hline Kadar air (\%) & 6,5 & 10,08 & 9,68 \\
\hline Kadar protein (\%) & 6,52 & 7,62 & 8,89 \\
\hline
\end{tabular}

\section{KESIMPULAN DAN SARAN}

Berdasarkan hasil penelitian dapat disimpulkan bahwa alat pengering terowongan Hohenheim dapat beroperasi dengan baik dalam mengeringkan kerupuk tiram berkualitas sehingga dapat direkomendasikan penggunaannya pada industri pengolahan kerupuk tiram. Alat pengering terowongan Hohenheim beroperasi dengan suhu pengeringan rata-rata $39,77^{\circ} \mathrm{C} \pm 4,42{ }^{\circ} \mathrm{C}$, dan $\mathrm{RH} 47,8-50,5 \%$, dengan kombinasi yang ideal untuk proses pengeringan yang lebih baik yaitu suhu ruang pengering lebih tinggi dari suhu lingkungan dan $\mathrm{RH}$ ruang pengering yang lebih rendah dari RH lingkungan. Pengeringan sangat efektif dilakukan dengan ketebalan lapisan pengeringan $6 \mathrm{~mm}$ sehingga kapasitas alat dapat ditingkatakn 3 kali lipat dari pengeringan dengan ketebalan lapisan $2 \mathrm{~mm}$. Salah satu kendala yang masih dihadapi adalah durasi proses pengeringan yang tidak dapat diselesaikan dalam waktu 8 jam menyebabkan proses pengeringan harus berhenti dan dilanjutkan pada hari berikutnya. Oleh karena itu penelitian lanjutan untuk adaptasi alat pengering terowongan Hohenheim sangat diperlukan untuk meningkatkan kinerja alat pengering dari sistem intermitten menjadi sistem kontinu.

\section{UCAPAN TERIMA KASIH}

Ucapan terima kasih tak terhingga kami sampaikan kepada Kementerian Riset, Teknologi dan Pendidikan Tinggi yang telah mendanai kegiatan Program Pengabdian Kepada Masyarakat tahun 2018.

\section{KONFLIK KEPENTINGAN}

Kami menyatakan bahwa tidak ada konflik kepentingan (confict of interest) dari berbagai pihak terhadap keluarnya publikasi ilmiah ini.

\section{DAFTAR PUSTAKA}

Al-Hasani, M., Zulfahrizal and Agustina, R. (2017). Kajian Variasi Ketebalan Tumpukan Fermentasi Terhadap Kualitas Pliek $U$ dan Minyak Pliek Yang Dikeringkan dengan Alat Pengering Tipe Hohenheim, Jurnal Ilmiah Mahasiswa Pertanian Unsyiah, 2(2), pp. 386-395.

Anggraini, T. and Yudhastuti, R. (2014). Penerapan Good Manufactoring Practices pada Industri Rumah Tangga Kerupuk Teripang di Sukolilo Surabaya, Jurnal Kesehatan Lingkungan, 7(2), pp. 148-158.

Berlia, M. et al. (2017). Analisis Usaha Dan Nilai Tambah Produk Kerupuk Berbahan Baku Ikan Dan Udang (Studi Kasus Di Perusahaan Sri Tanjung Kabupaten Indramayu), Perikanan dan Kelautan, 8(2), pp. 118-125.

BSN (2009). SNI Kerupuk Udang. Indonesia.

Hardi, A. (2019). Kajian Pengeringan Kopi Gayo Semi Basah Menggunakan Alat Pengering Tipe Hohenheim. Skripsi. Program Studi Teknik Pertanian Fakultas Pertanian Universitas Syiah Kuala.

Khathir, R., Agustina, R. and Jayanti, D. S. (2018). PKM Kellompok PKK Gampong Blang Kecamatan Meuraxa 'Pemberdayaan dan Peningkatan Ekonomi Masyarakat Desa Melalui Penerapan Teknologi Pengolahan Kerupuk Tiram', Laporan Pengabdian Masyarakat. Banda Aceh. doi: 10.1017/CBO9781107415324.004.

Khathir, R., Agustina, R. and Ratna, R. (2015). Karakteristik alat pengering tipe Hohenheim pada pengeringan 
Pliek-U, Seminar Nasional Hasil Riset dan Standardisasi Industri $V$, pp. 309-313.

Mentari, B., Nurba, D. and Khathir, R. (2017). Karakteristik Pengeringan Jahe Merah (Zingiber officinale Var Rubrum Rhizome) Dengan Metode Penjemuran Dan Menggunakan Alat Pengering Tipe Hohenheim, 2(2), pp. 439-448.

Mustamin, M., Asikin, H. and Mursydati, M. (2019). Daya Terima Kue Pia Dengan Substitusi Tepung Tiram (Crassostrea gigas) Pada Balita Stunting, Media Gizi Pangan, 26(1), pp. 85-93.

Puspita, P. (2017). Tiram Yang Kaya Nutrisi, Serba Serbi. Available at: https://bobo.grid.id/read/08674480/tiramyang-kaya-nutrisi (Accessed: 25 December 2019).

Rahmadi, R. (2019). Kajian Karakteristik Pengeringan Jahe Gajah (Zingiber offinale Rosc) Menggunakan Alat Pengering Tipe Hohenheim. Skripsi. Program Studi Teknik Pertanian Fakultas Pertanian Universitas Syiah Kuala.
Ridwan, Munawar, A. A. and Khathir, R. (2017). Peningkatan Kualitas Cabai Merah Kering Dengan Perlakuan Blanching Dalam Natrium Metabisulfit, Jurnal Ilmiah Mahasiswa Pertanian, 2(2), pp. 171-182.

Setiyorini, E. I. and Hadi, S. (2013). Pengaruh Penambahan Udang Rebon dan Jamur Tiram Terhadap Hasil jadi Kerupuk Udang Rebon, E-journal Boga, 2(1), pp. 44-50.

Zamharir, Sukmawaty and Priyati, A. (2016). Analisis Pemanfaatan Energi Panas Pada Pengeringan Bawang Merah (Allium Ascalonicum L.) Dengan Menggunakan Alat Pengering Efek Rumah Kaca (ERK), Jurnal Ilmiah Rekayasa Pertanian dan Biosistem, 4(2), pp. 264-274. 